\title{
Job Disamenities, Job Satisfaction, Quit Intentions, and Actual Separations: Putting the Pieces Together
}

\author{
Petri Böckerman \\ Labour Institute for Economic Research \\ and \\ Pekka Ilmakunnas \\ Helsinki School of Economics and HECER
}

Discussion Paper No. 166

May 2007

ISSN 1795-0562

HECER - Helsinki Center of Economic Research, P.O. Box 17 (Arkadiankatu 7), FI-00014 University of Helsinki, FINLAND, Tel +358-9-191-28780, Fax +358-9-191-28781, E-mail info-hecer@helsinki.fi, Internet www.hecer.fi 


\title{
Job Disamenities, Job Satisfaction, Quit Intentions, and Actual Separations: Putting the Pieces Together*
}

\begin{abstract}
We analyze the potential role of adverse working conditions at the workplace in the determination of employees' quit behavior. Our data contain both detailed information on perceived job disamenities, job satisfaction, and quit intentions from a cross-section survey and information on employees' actual job switches from longitudinal register data that can be linked to the survey. Reduced-form models show that employees facing adverse working conditions tend to have greater intentions to switch jobs and search for new matches more frequently. Multivariate probit models point out that job dissatisfaction that arises in adverse working conditions is related to job search and this in turn is related to actual job switches.
\end{abstract}

JEL Classification: J28, J31, J64.

Keywords: working conditions, job satisfaction, on-the-job search, job separation, quits.

\section{Petri Böckerman}

Labour Institute for Economic Research

Pitkänsillanranta $3 \mathrm{~A}$

FI-00530 Helsinki

FINLAND

e-mail: petri.bockerman@labour.fi
Pekka llmakunnas

Department of Economics

Helsinki School of Economics

P.O. Box 1210

FI-00101 Helsinki

FINLAND

e-mail: pekka.ilmakunnas@hse.fi

* This study has been funded by the Finnish Work Environment Fund (Työsuojelurahasto). An earlier version of this paper was presented at the Annual Conference of the Royal Economic Society, Warwick. The data can be accessed on site at the Research Laboratory of the Business Structures Unit of Statistics Finland. We are grateful to Satu Nurmi and Juha Honkkila for linking the data sets for our use. The usual disclaimer applies. This is an extensively updated version of HECER Discussion Paper No. 36. 
In the standard competitive labor market equilibrium there is no particular incentive for job separations to occur, since employees could not improve their labor market position by conducting a switch to another firm from their current matches. In contrast to this conjecture, there is a great deal of microlevel evidence on the dynamics of labor markets that points out that market economies are in a state of continuous turbulence (e.g. Davis and Haltiwanger 1999; Farber 1999). Accordingly, flows of workers between jobs and between labor market states are large by any reasonable standards.

Search theory and empirical search models typically concentrate on the role of a wage in explaining job changes. Another potential reason for the existence of job switch intentions and on-the-job search is adverse working conditions, which are without doubt a very important attribute of a job match. If the wage does not sufficiently compensate for adverse working conditions, employees can increase their utility by switching jobs. Although nonwage job characteristics can be included in search models (e.g. Blau 1991; Hwang et al. 1998; Lang and Majumdar 2004), this possibility has attracted more attention in the empirical work that is less directly tied to search models.

Extensive analysis of turnover has been made in human resource management (HRM) and personnel psychology, where attention centers on the personnel policies and job attitudes of the employees. There is also, however, an increasing interest in labor economics to incorporate information on working conditions and worker attitudes into the analysis of turnover. This paper contributes to the literature by analyzing the interactions between adverse working conditions, job satisfaction, employees' intentions to quit and actual separations within a uniform econometric framework that allows us to put together pieces of evidence that have been discovered in the literature.

Previously, empirical studies have analyzed directly how individual characteristics and working conditions or job attributes affect employees' probability of quitting or their job duration. Adverse working conditions have been found to increase quits. In most of these studies the data on working conditions are not from individual employees' workplaces, but rely on, for example, industry injury rates or work attributes typical of different occupations (e.g. Viscusi 1979; Bartel 1982; Herzog and Schottman 1990; Gronberg and Reed 1994). However, in some studies workplace-specific attributes are used. For instance, Manning (2003) uses information on night shifts to explain job duration. 
Another strand of the literature explains quits or job durations directly by means of job satisfaction scores, the employee's characteristics, and firm characteristics, but without information on job attributes (e.g. Flanagan et al. 1974; Freeman 1978; Clark et al. 1998; Ward and Sloane 2000; Clark 2001; Kristensen and Westergård-Nielsen 2004; Delfgaauw 2007; Lévy-Garboua et al. 2007). These studies discover that dissatisfied workers are more likely to quit their current matches. In other words, the self-reported level of job satisfaction is a good predictor for job mobility beyond the effect of wages. Working the other way, Akerlof, Rose and Yellen (1988) show that job changes lead to an increase in job satisfaction and Altonji and Paxson (1988) present evidence that job mobility leads to more satisfactory working hours.

In the HRM literature the relationships of job satisfaction, organizational commitment and withdrawal cognitions to actual turnover have been analyzed (e.g. Cotton and Tuttle 1986; Tett and Meyer 1993; Griffeth et al. 2000), using a variety of characteristics of the employees and firms. Variables that describe certain aspects of adverse working conditions have been included in some of these studies.

Furthermore, psychological studies show that the intentions of individuals are good predictors of their actual behavior (e.g. Steel et al. 1984; Tett and Meyer 1993). Similarly, Kristensen and Westergård-Nielsen (2004) report that job search, which is an extreme form of intentions to quit, is a good predictor of actual quits. When no data on actual separations has been available, the impact of working conditions and/or job satisfaction on quit intentions or job search has been examined in some studies in labor economics (e.g. van Ophem 1991; Shields and Price 2002; García-Serrano 2004; Sousa-Poza and Henneberger 2004) and the HRM literature (e.g. Hellman 1997).

Our purpose is to study employees' quit intentions and actual separations using Finnish data. The country has a fairly centralized wage bargaining system. The binding collective labor agreements already contain some pecuniary compensation for adverse working conditions. One could therefore think that working conditions may not matter a lot for quit intentions. However, the apparent heterogeneity of workplaces makes it hard for the collective labor agreements to take into account all the relevant aspects of working conditions. Collective agreements also lead to wage compression, which may prevent the creation of compensating wage differentials. Hence, employees' subjective valuations of their working conditions can differ greatly from the ones that have been stipulated in the collective agreements by the 
central organizations of employees and employers. Accordingly, our earlier evidence points out that perceived working conditions have a very minor role in the determination of individual wages in the Finnish labor market (Böckerman and Ilmakunnas 2006), in contrast to what the theory of compensating wage differentials would imply. Instead, adverse working conditions substantially increase the level of job dissatisfaction and the perception of unfairness of pay. It is therefore interesting to study whether this dissatisfaction gives rise to a desire to find another job.

This paper deviates from the earlier ones in this field of research in some important respects. First, we have a data set, the Quality of Work Life Survey of 1997, that includes not only job satisfaction scores, but also detailed information on several different aspects of working conditions at the workplace, not just conditions typical of the occupation or industry. It is possible to take advantage of this rich information on the prevalence of adverse working conditions as determinants of job satisfaction and employees' quit intentions. A drawback of the data set is that it is a single cross-section. On the other hand, there is a variety of information on both perceived job switch intentions and actual on-the-job search, so that different measures of employees' quit behavior can be compared. Second, the Quality of Work Life Survey can be matched to longitudinal, register-based employer-employee data maintained by Statistics Finland, which allows the identification of actual job switches of the survey respondents for the period (1998-2002) after the Quality of Work Life Survey was gathered. We can therefore analyze the degree to which employees' quit intentions and onthe-job search that may arise in the environment of adverse working conditions lead to actual job switches.

The data at hand make it possible to model the relationships between working conditions, job satisfaction, and employees' quit behavior. In the first reduced-form models, we explain alternative binary indicators of quit intentions and actual job switches by individual characteristics, firm characteristics, and measures for adverse working conditions. In the second, extended model, we examine the interrelationships of the variables in more detail. We first explain the binary indicator of job satisfaction with adverse working conditions and by industry and occupation indicators. A binary indicator of quit intentions is then explained by job satisfaction and the employees' personal characteristics. Finally, actual job switches obtained from the longitudinal employer-employee data are explained by quit intentions, wage, and some other personal characteristics. This model forms a system of probit models that have endogenous dummy explanatory variables. Since the system is recursive, it can be 
estimated as a multivariate probit model. This approach is similar to that used by Shields and Price (2002) and Antecol and Cobb-Clark (2005), but they used only one very specific indicator of working conditions, racial harassment. In addition, they derive their results from data covering a very specific labor market (i.e. British nurses and US military, respectively) making it difficult to generalize the results obtained, and they do not incorporate information on actual job switches. Furthermore, Scott et al. (2006) estimate a closely related structural model for job satisfaction and intentions to quit, but they do not study actual job switches and the model is not estimated in a multivariate framework.

In this article, we discover that employees currently facing adverse working conditions have greater intentions to switch jobs and also search for new jobs more frequently. Multivariate probit models point out that job dissatisfaction that arises in adverse working conditions is related to job search and this in turn is related to actual job switches.

The paper proceeds as follows. We first describe our hypotheses and the modeling approaches. An overview of the data is provided next. The results are then presented and a summary concludes.

Hypotheses and Modeling Approaches

Explaining Employees' Quit Intentions and Actual Job Switches With Job Disamenities. We start the analysis with reduced-form models to test the hypothesis of compensating wage differentials. Assume that quit intentions and actual quits depend on wage and job disamenities, and wage adequately compensates for the disamenities. Then the disamenities should have no independent effect on intentions to quit and separations. However, based on the literature, we can expect that the prevalence of perceived job disamenities increases employees' quit intentions and actual job separations even when we do not include wage among the explanatory variables. This may arise from labor market imperfections like imperfect information, collective bargaining (e.g. Daniel and Sofer 1998), and various frictions in labor markets (e.g. Manning 2003). If wage was included, the equation could in principle give the wage-disamenity trade-off (e.g. Herzog and Schottman 1990). We use probit models where we explain binary indicators of quit intentions and actual job switches directly by means of adverse working conditions. ${ }^{1}$ We have several alternative measures for quit intentions, which are explained in the next section. As explanatory variables we have dummy variables that describe various aspects of disamenities and various individual and 
workplace characteristics. It is important to note that when we estimate the probit model for actual job separations we assume that job satisfaction and job disamenities in 1997 reflect the values of these variables as long as the individuals stay in the same plant over the five-year period (1998-2002). ${ }^{2}$

The choice of explanatory variables is partly determined by arguments from the large literature on job search in the labor market (e.g. Eckstein and Van den Berg 2007). The probability of quitting should decrease with tenure, because longer current tenure is consistent with a longer implicit search process that has not yet led to a job switch. This increases the overall probability that the current match between a worker and a firm is among the best available in the labor market. While much of the work deals with search when the worker unemployed, there have been empirical analyses of on-the-job search by Blau (1992), Pissarides and Wadsworth (1994), and Manning (2003), among others.

There are other important variables that have a potential influence on on-the-job search and actual job switches. Empirical studies have demonstrated that there are employee characteristics such as age, gender, marital status, and education that are important determinants of on-the-job search. In addition, past job changes have been found to predict future separations (e.g. Munasinghe and Sigman 2004). Controlling for past labor market behavior may also help in obtaining a coefficient for tenure that is not affected by worker heterogeneity in the propensity to quit.

In addition to the individual employees' characteristics, we also include, among the explanatory variables, various characteristics of the workplace, like indicators of high performance work practices (team work), plant size, industry, and the regional unemployment rate. A complete list of the variables is explained in detail in the next section.

Interaction of Disamenities, Satisfaction, Quit Intentions and Actual Job Switches. The second model is formed to test the hypothesis that job disamenities decrease job satisfaction, which in turn has an impact on employees' quit intentions that finally matter for actual job separations. Formally, in the first step we explain our measure of job satisfaction by discrete measures of disamenities and with some other variables that describe the workplace. The true, unobserved (latent) job satisfaction is a continuous variable $z^{*}$, which is explained by the variables $\mathrm{X}_{1}$. We observe the binary measure of job satisfaction $\mathrm{z}$, if the latent measure is greater than zero. The model and the observation rule are therefore 
$\mathrm{Z}_{\mathrm{i}}^{*}=\mathrm{X}_{1 \mathrm{i}} \beta_{1}+\varepsilon_{1 \mathrm{i}}$

$\mathrm{z}_{\mathrm{i}}=\mathbf{1}\left(\mathrm{z}_{\mathrm{i}}^{*}>0\right)$

where 1(.) is an indicator variable and $i$ indexes the individuals. In the second stage, quit intentions are explained by the observed binary job satisfaction variable $\mathrm{z}$ and variables $\mathrm{X}_{2}$. Again, there is an underlying unobserved continuous measure of quit intensity $\mathrm{q}^{*}$, which is observed as a binary indicator q of observed quit intention or on-the-job search. We refer to this as the quit intentions equation:

$\mathrm{q}_{\mathrm{i}}^{*}=\gamma \mathrm{Z}_{\mathrm{i}}+\mathrm{X}_{2 \mathrm{i}} \beta_{2}+\varepsilon_{2 \mathrm{i}}$

$\mathrm{q}_{\mathrm{i}}=\mathbf{1}\left(\mathrm{q}_{\mathrm{i}}^{*}>0\right)$

This second equation gives, in principle, the wage-satisfaction trade-off. In the final stage of our analysis, actual job switches are explained by means of the observed quit intentions $q$ and variables $\mathrm{X}_{3}$ :

$\mathrm{s}_{\mathrm{i}}^{*}=\delta \mathrm{q}_{\mathrm{i}}+\mathrm{X}_{3 \mathrm{i}} \beta_{3}+\varepsilon_{3 \mathrm{i}}$

$\mathrm{s}_{\mathrm{i}}=\mathbf{1}\left(\mathrm{s}_{\mathrm{i}}^{*}>0\right)$

where $\mathrm{s}^{*}$ is latent job switch and s a binary indicator for observed actual job switch.

It is assumed that at all stages there are unobserved individual characteristics and therefore the error terms of the different stages are correlated. For this reason, these estimation results may differ from the ones based on reduced-form models that have been used more frequently in the literature. The unobserved individual characteristics can, for example, be attitudinal factors stressed in the HRM literature on mobility or individual characteristics that affect occupational choice or unobservable productivity characteristics that are not captured by the traditional human capital variables that are available in the Quality of Work Life Survey. The three equations form a system of discrete dependent variable models with endogenous dummy explanatory variables. ${ }^{3}$ The model is recursive in the sense that job satisfaction explains quit intentions and quit intentions explain actual quits, but job switches do not explain intentions to quit or job satisfaction, and intentions to quit do not explain satisfaction. Because of this recursive structure, and assuming normally distributed errors, the model can be estimated as a multivariate probit model (e.g. Greene 2003). We use the Geweke-Hajivassiliou-Keane 
(GHK) simulated maximum likelihood estimator implemented to Stata by Cappelari and Jenkins (2003).

To identify the parameters of the model it is not necessary that the variables $\mathrm{X}_{1}, \mathrm{X}_{2}$, and $\mathrm{X}_{3}$ are different (Wilde 2000), since the model can be identified through the nonlinear functional form. However, it is still good practice to exclude some variables from the equations. ${ }^{4}$ There is no comprehensive theory that would give sharp predictions about which variables should be included in the Xs, because the role of non-wage job attributes is mostly analyzed in the empirical literature that is not directly linked to search models. Based on the discussion above and our results by using the same data (Böckerman and Ilmakunnas 2006), we include in $X_{1}$ occupation and industry dummies that do not appear in the other equations, and some characteristics of individual workers, like education, which appear in the other equations. In addition, $X_{1}$ contains some employer features like plant size that have been found to affect job satisfaction (e.g. Clark 1996). In $\mathrm{X}_{2}$ we incorporate more personal characteristics, including wage. As discussed above, in a compensating differentials framework wage and job disamenities should wipe out each other. However, as there are most likely labor market imperfections that prevent compensating differentials from operating, we include them both. This also gives the wage-disamenity trade-off. Finally, $\mathrm{X}_{3}$ comprises wage and variables that are related to the individual, but some variables are excluded from $\mathrm{X}_{3}$ that are included in $\mathrm{X}_{2}$ (two measures for the payment system at the workplace). Further, $\mathrm{X}_{3}$ contains the regional unemployment rate that is not included in $\mathrm{X}_{2}$, or in $\mathrm{X}_{1}$. Regional disparities in unemployment are substantial in Finland. Therefore, it is reasonable to assume that regional labor market conditions greatly matter for one's success in realizing job switch aspirations. ${ }^{5}$

\section{Data}

The primary data set that we are using in this paper is the Quality of Work Life Survey (QWLS) of Statistics Finland (SF). It is conducted at irregular intervals. We use the data from the year 1997. The initial sample for QWLS is derived from a monthly Labour Force Survey (LFS), where a random sample of the working age population is selected for a telephone interview. The 1997 QWLS was based on LFS respondents in September and October who were 15-64-year-old wage and salary earners with a normal weekly working time of at least five hours. 3795 individuals were selected for the QWLS sample and invited to participate in a personal face-to-face interview. Out of this sample, 2978 persons or around 78 percent participated (Lehto and Sutela 1999) in the interviews, which took place in the period 
between September and December. Owing to missing information on some variables for some workers, the sample size used in this study is around 2750 observations.

The QWLS survey contains a number of questions about the subjective views of workers with respect to their working conditions, as well as about the perceived job satisfaction. In addition, QWLS includes information on the personal characteristics and work experience of the respondents. SF supplements QWLS with information from the LFS on, for example, working time and exact labor market status. Supplementary information on the industry and location of the employer as well as annual earnings and the level and field of education of the respondents was gathered from various registers maintained by SF. The variables that we are using and descriptive statistics are documented in Appendix (Table A1).

The phenomena that we are interested in explaining are employees' quit intentions and actual job switches. We have information on those employees who would change jobs within the same occupational field, if they could receive the same pay as now (around 24 percent of employees), and on those who would switch for the same level of pay to another occupational field (around 25.5 percent). ${ }^{6}$ From these measures we can derive an indicator of intentions to quit, Switch Intentions, which is the sum of the two sub-cases (49.5 percent). ${ }^{7}$

As to on-the-job search behavior, we have two measures that are used in the models. Searcher Last Six Months is a dummy variable that indicates that the employee has looked for another job at some stage during the last six months (15.2 percent of the employees). Searcher Last Four Weeks is a dummy for employees that have searched for a job during the last four weeks (6.4 percent of employees). There is one inconsistency between the measures that capture actual job search. Among those that report having looked for another job in the last four weeks 14.8 percent say that they have not looked for another job in the last six months. An explanation for this is that the Searcher Last Six Months variable comes from the QWLS questionnaire filled in during a personal interview, whereas the Searcher Last Four Weeks variable comes from the LFS telephone survey that is done before the QWLS questionnaire is filled. It is possible that some respondents have forgotten what they answered in the LFS survey and some respondents may have thought that six months is "the last six months, not accounting for the last four weeks".

The QWLS data is a cross-section data set that does not as such include any information on actual job switches. However, the QWLS data can be matched to longitudinal register data, 
FLEED (Finnish Longitudinal Employer-Employee Data). FLEED is constructed from a number of different registers on individuals and firms that are maintained by Statistics Finland. In particular, FLEED contains information from Employment Statistics, which records each employee's employer during the last week of each year. ${ }^{9}$ Matching of these data sources is possible, because both the QWLS data and FLEED contain the same unique personal identifiers (i.e. ID codes for persons). We have followed the employees over the period of 1998-2002, since it may take some time before intentions to quit and on-the-job search finally materialize as actual job switches. This is a particularly relevant point in the environment of persistent unemployment, where the number of suitable vacancies is limited. This has been the situation in Finland, since unemployment has been high since a deep recession in the early 1990s. (According to LFS, the unemployment rate in Finland was 12.7 in 1997.) Actual job switches of the employees are defined based on changes in the employer plant codes. Using plants rather than firms to define the job switches matches, as closely as possible, the information in the QWLS data, because the questions on adverse working conditions refer to the plant level. Our measure for actual job switches or separations is Actual Switch, which obtains value one when an employee is during the period 1998-2002 at least once in a different plant than in 1997 (38.4 percent of the employees). Unfortunately the data set has no information on the reasons for terminating the employment relationship, so we cannot distinguish between quits and layoffs. ${ }^{10}$

Because the connection between intentions to quit and actual mobility has rarely been analyzed in the literature, it is useful to provide some descriptive evidence. Simple cross tabulations of the variables show that Actual Switch is most closely associated with a dummy that captures employees who have searched for another job during the last four weeks. 50.3 percent of those who have searched during the last four weeks have actually changed their job over the period 1998-2002. The corresponding shares for Switch Intentions and Searcher Last Six Months are $42.0 \%$ and $46.6 \%$, respectively.

Job satisfaction in the QWLS data is measured by the alternatives 1 (very satisfied: 30.6 percent of respondents), 2 (quite satisfied: 63.1 percent), 3 (rather dissatisfied: 5.3 percent), and 4 (very dissatisfied: 1 percent). We form a job satisfaction dummy (Satisfied) that indicates the highest satisfaction category 1 .

The subjective valuations of harms and hazards related to working conditions are measured in the QWLS survey by the use of different categories. For perceived harms, there is a five-point 
scale in which the highest category corresponds to the perception by a worker that a feature of working conditions is 'very much' an adverse factor at the workplace. For perceived hazards, the highest category among three possibilities is the one in which the respondent considers a feature at the workplace as 'a distinct hazard'. Responses to the questions about adverse working conditions can be aggregated by forming a dummy variable that equals one if there is at least one clearly adverse factor (Harm) and a dummy that equals one if there is at least one distinct hazard (Hazard). These variables capture largely different aspects of the work environment.

We use the following dummy variables as other job disamenities. Uncertainty indicates that there is at least one clear insecurity factor at the workplace and Neglect is a dummy for the existence of at least one aspect where the worker gets no support from superiors. Additionally, we have a dummy variable for mentally very demanding work (Heavy Mentally), poor advancement opportunities (No Promotion), and discrimination at the workplace (Discrimination). We include a large set of control variables, which can be regarded as 'the usual suspects' based on the literature (see Table A1).

\section{Findings}

Results from Reduced-form Models. We estimate probit models for job switch intentions, onthe-job search and actual job switches. The explanatory variables are the same in all four models. To make the results easier to read, we report marginal effects instead of parameter estimates in Table 1. For the dummy variables the entries in the table are differences of probabilities evaluated at values 1 and 0 of the dummy. The results show that employees currently facing adverse working conditions have more intentions to change their matches. ${ }^{11}$ In particular, those who are more willing to change their jobs are those who face at least one notable harm or factor of uncertainty, those who feel neglected by their superiors, have mentally heavy work, feel that they have no promotion chances or face discrimination (Table 1, Column 1). Based on the evidence, the only perceived job disamenity that does not have an influence on intentions to quit is the one that captures hazards. ${ }^{12}$

Employees currently facing unpleasant working conditions tend to search for new jobs more frequently (Table 1, Columns 2-3). Uncertainty and poor promotion chances have a clear positive impact on both of the on-the-job search variables. Job search during the last six months is also positively affected by the feel of neglect and the prevalence of discrimination. 
Furthermore, job search during the last four weeks is intensified by the existence of at least one perceived harm.

The marginal effects of the disamenity variables on on-the-job search are lower than on job switch intentions, as could be expected, since actual search requires more active involvement than intentions. The pseudo $\mathrm{R}^{2}$ of the models is higher when on-the-job search is explained than in the models for job switch intentions or actual job switches. One interpretation of this is that unobservable individual characteristics are more important in the determination of intentions and actual job switches.

Adverse working conditions are much less tied to actual job switches than to job switch intentions or on-the-job search, based on the reduced-form models (Table 1, Column 4). This is particularly interesting, because the effects of perceived working conditions on actual job separations have not been examined previously. The only variables describing adverse working conditions that get the expected positive coefficients at least at the $10 \%$ significance level are the dummy variables for mentally heavy work and discrimination. In contrast, those who are employed at a workplace with at least one hazard, feel neglect and have no promotion prospects have been less likely to actually switch their jobs over the period 1998-2002. ${ }^{13}$ This finding may emerge, for instance, because those employees have poor unobservable productivity characteristics that are not captured by our standard human capital variables. This would explain the fact that they are stuck at workplaces with adverse working conditions and face difficulties in finding a suitable new match at the same time. Naturally, the omitted variable of personal productivity could also have an influence on our results for intentions to quit and job search. As explained earlier, unobservable individual characteristics provide the most important motivation to estimate multivariate probit models, where the correlation between the error terms of the equations is allowed.

Taken together, our results point out that uncontrolled variation in wage is not enough to compensate for the effects of job disamenities, because they have an independent effect on employees' intentions to quit. Accordingly, labor markets are in disequilibrium at any given point of time in the sense that employees located in adverse working conditions are forced to look for outside opportunities in order to improve their labor market position. This is inconsistent with the existence of adequate compensating wage differentials for adverse working conditions, but consistent with frictions and non-competitive labor markets as outlined, for example, by Manning (2003). 
We briefly summarize some interesting results concerning the control variables included. Employees with temporary contracts and part-timers search for new jobs more frequently (Table 2, Columns 2-3). ${ }^{14}$ Education has a positive impact on job switch intentions and onthe-job search. It is likely that more educated workers face more opportunities in the labor market, because the unemployment rate is much lower for the highly educated.

Work history seems to matter, although the results vary across models. Tenure has an inverted U-shaped effect on job switch intentions (with the maximum at 10.5 years of tenure), but in the other equations the tenure effect is not significant. Previous changes in occupation and previous job switches predict current on-the-job search (Table 1, Column 2), which is in accordance with the "hobo syndrome" reported by Munasinghe and Sigman (2004).

Employees in foreign-owned companies and in companies that are financially unstable have more job switch intentions. There is less search activity in regional labor markets with a high unemployment rate. This may be a sign of the discouraged worker effect. Furthermore, high regional unemployment restricts actual job switches, as expected.

Overall, the results concerning the control variables vary across the models. This shows that our different measures of quit intentions describe slightly different kinds of labor market behavior. Encouragingly, the influence of adverse working conditions is somewhat more consistent across the models than the impact of specific worker or firm characteristics. ${ }^{15}$

Results from Multivariate Probit Models. We estimate three different joint models for job satisfaction, quit intentions and actual job switches. These models use our three alternative quit intention measures. Otherwise the structure of all models is identical. We concentrate on the six job disamenities, Harm, Hazard, Uncertainty, Heavy Mentally, No Promotion, and Discrimination. Besides these, Satisfied was explained in the first stage of the multivariate models by variables that describe the employment relationship (Temporary, Part-Timer), the workplace (Shift Work, Team Work, Public Sector, Foreign Firm, dummies for plant size, 14 industry dummies), occupation (10 occupation dummies), and the individual's basic characteristics (Female, Age, Age Squared, dummies for education levels, Union Member). ${ }^{16}$

We have as the dependent variable in the second stage of the models one of our three alternative quit intention measures, Switch Intentions, Searcher Last Six Months, or Searcher Last Four Weeks. In all the alternative models the explanatory variables for quit intentions 
included Satisfied, Wage, other variables describing the pay system (Fixed Pay, Piece Rate), the employment relationship variables, managerial position (Manager), variables that describe the employer's prospects (Growing Employment, Unstable Firm), work history variables (Tenure, Tenure Squared, Different Occupations, Number of Switches), the individual's characteristics, and family-related variables. Finally, to explain actual job switches we included our measure for quit intentions (Switch Intentions, Searcher Last Six Months, or Searcher Last Four Weeks), all the variables included as explanatory variables in the quit intentions equation (except the ones for the payment system and Satisfied), and Regional Unemployment.

The justification for the choice of variables (i.e. exclusion restrictions) is the following. The job satisfaction equation includes disamenities, workplace variables, and occupation that can be thought to affect individual's attitude towards one's job, but should have no direct relationship to planned or actual job switches. The other two equations include variables that relate to comparisons of alternative jobs (wage variables), variables that describe constraints to job switches (family variables), and variables that describe the individual's labor market mobility in the past and therefore should predict quit intentions and behavior. Furthermore, a firm's poor prospects may give rise to job switches. All of these variables are such that they should have no direct connection to job satisfaction. Regional unemployment should affect the realization of actual switches, rather than search and intentions.

The most important results from multivariate probit models are summarized in Table 2 . The results are reported in Table 2 in the following way. We have three alternative variables for quit intentions (Switch Intentions, Searcher Last Six Months, and Searcher Last Four Weeks) out of which only one at a time is included. We therefore have three different models to estimate, which are reported in different columns of the table. Each column begins with the description of the dependent variables in the three different stages of the multivariate model. For each model, the first section (1) of the table reports the coefficients of job disamenities from the equation for job satisfaction. The second section (2) documents the coefficients of Satisfied and Wage in the quit intention equation. The third section (3) of the table reports the coefficients of the quit intention variable and Wage from the equation for actual job switches. Accordingly, Table 2 documents the main coefficients of interest from three alternative models estimated. The coefficients of the other explanatory variables included are not reported in the table to save space. Note that the figures in the table are the estimated 
coefficients, not the marginal effects, which would vary between different combinations of outcomes for actual job switches, employees' quit behavior and satisfaction.

The results that are reported in the first section of Table 2 reveal that the prevalence of job disamenities systematically decreases the level of job satisfaction, which is consistent with our earlier findings (Böckerman and Ilmakunnas 2006). In addition, the prevalence of job dissatisfaction systematically intensifies the likelihood of quit intentions with all three alternative measures (Table 2, section (2)). The results are statistically significant at the $1 \%$ level and in keeping with the literature that was discussed in the Introduction. For example, Satisfied gets a negative coefficient (with robust z-statistic -9.08) in the model in which Switch Intentions are explained in the second stage of the multivariate model. Furthermore, job search during the last four weeks increases the likelihood of actual job switches when it is used as the intentions variable (Table 2, section (3)). This finding is in accordance with the simple cross tabulations of the variables that show that Actual Switch is most closely associated with a dummy that captures employees who have searched for another job during the last four weeks, as discussed earlier. The results on Switch Intentions are weaker. ${ }^{17}$ In summary, our estimation results reveal that the prevalence of perceived adverse working conditions increases the level of job dissatisfaction and dissatisfaction drives job search and this in turn induces actual job switches. ${ }^{18}$

The coefficients of the wage variable are relatively low in the quit intentions equations. In principle, we could use the coefficients of wage and satisfaction in these equations to evaluate the monetary value of job satisfaction, i.e. wage compensation that would be needed to compensate for dissatisfaction to keep the probability of job search constant (Herzog and Schottman 1990). However, the figure calculated in this way is too large to be a reasonable estimate. (The coefficients of satisfaction are approximately ten times the absolute value of the corresponding coefficients of (log) wage in section (2) of Table 2.)

\section{Conclusions}

This paper analyzed the role of adverse working conditions in the determination of employees' quit behavior. We took advantage of the Finnish Quality of Work Life Survey, which includes not only job satisfaction scores, but also detailed information on several different aspects of perceived working conditions at the workplace, not just conditions typical of the occupation or industry that have been more commonly used in research. Moreover, the 
QWLS data contains several different measures for quit intentions ranging from job switch intentions to the conduct of on-the-job search.

A great advantage of the survey is that it can be matched to longitudinal employer-employee data, which contain comprehensive information on employees' actual job switches. This allowed us to analyze the degree to which job dissatisfaction that may arise in adverse working conditions affects employees' quit intentions and on-the-job search and how this behavior transforms itself into actual job switches. This is important, because the existing literature has almost exclusively examined only parts of this 'chain'. For reasons of data availability, some studies have explained only quit intentions, and some have explained only actual quits. The data often restricts also the explanatory variables that can be used. For example, there is a substantial body of research that explains quits directly by means of job satisfaction scores, but without information on job attributes. We were able to investigate the issue within a uniform econometric framework that allowed us to put together a number of different correlations that have been documented in the earlier literature. This paper demonstrates that conventional wisdom in the area that is largely based on partial correlations can be extended to give a richer picture of the process.

Our results from reduced-form models in which quit intentions are directly explained by individual characteristics, firm characteristics and indicators for working conditions show that those currently facing adverse working conditions have greater job switch intentions and search for new matches more frequently. Labor markets are therefore in disequilibrium at any given point of time in the sense that workers in adverse working conditions are forced to look for outside opportunities to improve their labor market position. It turns out that our different measures of quit intentions describe slightly different kinds of labor market behavior. The influence of adverse working conditions is somewhat more consistent across the models than the impact of specific worker or firm characteristics. Furthermore, adverse working conditions and actual job switches are much less connected than adverse working conditions and switch intentions or on-the-job search, based on the evidence from reduced-form models.

The estimation of recursive multivariate probit models makes it possible to take into account the correlation between the error terms of the equations for job satisfaction, employees' intentions to quit and actual job switches. The correlation emerges from unobservable individual characteristics that can be associated with employees' attitudes and productivity, among other things. We find that job disamenities decrease job satisfaction and the prevalence 
of job dissatisfaction systematically intensifies job search among the affected workers. This in turn leads to actual job switches. The pattern arises despite the high unemployment that seriously limits employees' opportunities for finding suitable vacancies. The results for intentions to quit are weaker. This finding is in line with thinking that job search is a good predictor of actual job separations, because it constitutes an extreme form of intentions to quit, as argued in some earlier studies. All in all, our results call for more empirical studies that combine information from linked employer-employee data sources covering the "whole chain' from job disamenities through job satisfaction to actual job switches. In particular, the use of linked data sets that contain survey information combined with register data make it possible to evaluate in detail the connection between subjective viewpoints and objective labor market outcomes, to which the literature has not paid much attention.

\section{References}

Akerlof, George A., Andrew Rose, and Janet L. Yellen. 1988. "Job Switching and Job Satisfaction in the US Labor Market.” Brookings Papers on Economic Activity 2:177-248.

Altonji, Joseph G., and Christina H. Paxson. 1988. "Labor Supply Preferences, Hours Constraints, and Hours-wage Trade-offs.” Journal of Labor Economics 6:254-276.

Antecol, Heather, and Deborah Cobb-Clark. 2005. "Racial Harassment, Job Satisfaction and Intentions to Remain in the Military." Discussion Paper No. 1636, IZA.

Bartel, Ann P. 1982. "Wages, Nonwage Job Characteristics, and Labor Mobility.” Industrial and Labor Relations Review 35:578-589.

Blau, David M. 1991. "Search for Nonwage Job Characteristics: A Test of the Reservation Wage Hypothesis.” Journal of Labor Economics 9:186-205.

Blau, David M. 1992. “An Empirical Analysis of Employed and Unemployed Job Search Behaviour." Industrial and Labor Relations Review 45:738-752.

Brown, Charles. 1980. “Equalizing Differences in the Labor Market.” The Quarterly Journal of Economics 94:113-134. 
Böckerman, Petri, and Pekka Ilmakunnas. 2006. "Do Job Disamenities Raise Wages or Ruin Job Satisfaction?” International Journal of Manpower 27:290-302.

Cappelari, Lorenzo, and Stephen P. Jenkins. 2003. "Multivariate Probit Regression Using Simulated Maximum Likelihood." Stata Journal 3:278-294.

Clark, Andrew E., Georgellis Yannis, and Peter Sanfey. 1998. "Job Satisfaction, Wage Changes, and Quits: Evidence from Germany." Research in Labor Economics 17:95-121.

Clark, Andrew E. 1996. "Job Satisfaction in Britain.” British Journal of Industrial Relations, 34:189-217.

Clark, Andrew E. 2001. "What Really Matters in a Job? Hedonic Measurement Using Quit Data." Labour Economics 8:223-242.

Cotton, John L., and Jeffrey M. Tuttle. 1986. "Employee Turnover: A Meta-analysis and Review with Implications for Research.” Academy of Management Review 11:55-70.

Daniel, Christophe and Catherine Sofer. 1998. "Bargaining, Compensating Wage Differentials, and Dualism of the Labor Market: Theory and Evidence for France." Journal of Labor Economics 16:546-575.

Davis, Steven J., and John Haltiwanger. 1999. "Gross Job Flows.” In Handbook of Labor Economics, Volume 3B, edited by Orley Ashenfelter and David Card, pp. 2711-2805. Amsterdam: Elsevier.

Delfgaauw, Josse. 2007. "The Effect of Job Satisfaction on Job Search: Not Just Whether, But Also Where." Labour Economics (forthcoming).

Eckstein, Zvi, and Gerard G. Van den Berg. 2007. "Empirical Labor Search: A Survey." Journal of Econometrics 136:531-564.

Farber, Henry S. 1999. "Mobility and Stability: The Dynamics of Job Change in Labor Markets." In Handbook of Labor Economics, Volume 3B, edited by Orley Ashenfelter and David Card, pp. 2439-2483. Amsterdam: Elsevier. 
Flanagan, Robert J., Gary Strauss, and Lloyd Ulman. 1974. "Worker Discontent and Work Place Behavior.” Industrial Relations 13:101-123.

Freeman, Richard. 1978. "Job Satisfaction as an Economic Variable." The American Economic Review 68:135-141.

García-Serrano, Carlos. 2004. “Temporary Employment, Working Conditions and Expected Exits from Firms." Labour: Review of Labour Economics and Industrial Relations 18:293316.

Greene, William H. 2003. Econometric Analysis, $5^{\text {th }}$ ed. Upper Saddle River, NJ: Prentice Hall.

Griffeth, Rodger W., Peter W. Hom, and Stefan Gaertner. 2000. “A Meta-analysis of Antecedents and Correlates of Employee Turnover: Update, Moderator Tests, and Research Implications for the Next Millennium.” Journal of Management 26:463-488.

Gronberg, Timothy J., and W. Robert Reed. 1994. "Estimating Workers' Marginal Willingness to Pay for Job Attributes Using Duration Data." Journal of Human Resources 29:911-931.

Heckman, James J. 1978. "Dummy Endogenous Variables in a Simultaneous Equation System." Econometrica 46:931-959.

Hellman, Chan M. 1997. “Job Satisfaction and Intent to Leave.” Journal of Social Psychology 137:677-689.

Herzog, Henry W., and Alan M. Schottmann. 1990. "Valuing Risk in the Workplace: Market Price, Willingness to Pay, and the Optimal Provision of Safety." Review of Economics and Statistics 71:463-470.

Hwang, Hae-Shin, Dale T. Mortensen, and W. Robert Reed. 1998. "Hedonic Wages and Labor Market Search.” Journal of Labor Economics 16:815-847. 
Hyytinen, Ari, and Pekka Ilmakunnas. 2007. "Entrepreneurial Aspirations: Another Form of Job Search?" Small Business Economics (forthcoming).

Kristensen, Nicolai, and Niels Westergård-Nielsen. 2004. "Does Low Job Satisfaction Lead to Job Mobility?” Discussion Paper No. 1026, IZA.

Laband, David N., and Bernard F. Lentz. 1998. "The Effects of Sexual Harassment on Job Satisfaction, Earnings, and Turnover Among Female Lawyers." Industrial and Labor Relations Review 51:594-607.

Lang, Kevin, and Sumon Majumdar. 2004. "The Pricing of Job Characteristics When Markets Do Not Clear: Theory and Policy Implications." International Economic Review 45:11111128.

Lehto, Anna-Maija, and Hanna Sutela. 1999. "Efficient, More efficient, Exhausted. Findings of Finnish Quality of Work Life Surveys 1977-1997." Statistics Finland, SVT: Labour Market 1999:8.

Lévy-Garboua, Louis, Claude Montmarquette, and Véronique Simonnnet. 2007. "Job Satisfaction and Quits.” Labour Economics 14:251-268.

Maddala, G.S. 1983. Limited-dependent and Qualitative Variables in Econometrics. Cambridge: Cambridge University Press.

Manning, Alan. 2003. Monopsony in Motion. Imperfect Competition in Labor Markets, Princeton: Princeton University Press.

Monfardini, Chiara, and Rosalba Radice. 2006. "Testing Exogeneity in the Bivariate Probit Model: A Monte Carlo Study." Department of Economics, University of Bologna, Unpublished.

Munasinghe, Lalith, and Karl Sigman. 2004. “A Hobo Syndrome? Mobility, Wages, and Job Turnover." Labour Economics 11:191-218. 
Pissarides, Christopher A., and Jonathan Wadsworth. 1994. "On-the-Job Search: Some Empirical Evidence from Britain.” European Economic Review 38:385-401.

Monfardini, Chiara, and Rosalba Radice. 2006. "Testing Exogeneity in the Bivariate Probit Model: A Monte Carlo Study." Department of Economics, University of Bologna, Unpublished.

Scott, Anthony, Hugh Gravelle, Steven Simoens, Chris Bojke, and Bonnie Sibbald. 2006. "Job Satisfaction and Quitting Intentions: A Structural Model of British General Practitioners.” British Journal of Industrial Relations 44:519-540.

Shields, Michael A., and Stephen W. Price. 2002. "Racial Harassment, Job Satisfaction and Intentions to Quit: Evidence from the British Nursing Profession.” Economica 69:295-326.

Sousa-Poza, Alfonso and Fred Henneberger. 2004. "Analyzing Job Mobility with Job Turnover Intentions: An International Comparative Study." Journal of Economic Issues 38:113-137.

Steel, Robert P., and Nestor K. Orvalle II. 1984. "A Review and Meta-Analysis of Research on the Relationship Between Behavioral Intentions and Employee Turnover." Journal of Applied Psychology 69:673-686.

Tett, Robert P. and John P. Meyer. 1993. "Job Satisfaction, Organizational Commitment, Turnover Intention, and Turnover: Path Analyses Based on Meta-analytic Findings." Personnel Psychology 46:259-293.

Van Ophem, Hans. 1991. "Wages, Nonwage Job Characteristics and the Search Behavior of Employees." Review of Economics and Statistics 73:145-151.

Wilde, Joachim. 2000. "Identification of Multiple Equation Probit Models with Endogenous Dummy Regressors.” Economics Letters 69:309-312. 
TABLE 1: MARGINAL EFFECTS FROM REDUCED-FORM PROBIT MODELS

\begin{tabular}{|c|c|c|c|c|}
\hline & $\begin{array}{l}\text { Switch } \\
\text { Intentions, } \\
\text { Probit model }\end{array}$ & $\begin{array}{l}\text { Searcher Last } \\
\text { Six Months, } \\
\text { Probit model }\end{array}$ & $\begin{array}{l}\text { Searcher Last } \\
\text { Four Weeks, } \\
\text { Probit model } \\
\end{array}$ & $\begin{array}{l}\text { Actual Switch, } \\
\text { Probit model }\end{array}$ \\
\hline Harm & $\begin{array}{l}0.070 \\
(2.95)^{* * *}\end{array}$ & $\begin{array}{l}0.006 \\
(0.46)\end{array}$ & $\begin{array}{l}0.018 \\
(2.56)^{* *}\end{array}$ & $\begin{array}{l}0.024 \\
(1.02)\end{array}$ \\
\hline Hazard & $\begin{array}{l}0.013 \\
(0.57)\end{array}$ & $\begin{array}{l}0.018 \\
(1.37)\end{array}$ & $\begin{array}{l}-0.000 \\
(0.07)\end{array}$ & $\begin{array}{l}-0.041 \\
(1.83)^{*}\end{array}$ \\
\hline Uncertainty & $\begin{array}{l}0.097 \\
(4.55)^{* * *}\end{array}$ & $\begin{array}{l}0.025 \\
(2.05)^{* *}\end{array}$ & $\begin{array}{l}0.014 \\
(2.19)^{* *}\end{array}$ & $\begin{array}{l}0.008 \\
(0.37)\end{array}$ \\
\hline Neglect & $\begin{array}{l}0.053 \\
(2.10)^{* *}\end{array}$ & $\begin{array}{l}0.042 \\
(2.88)^{* * *}\end{array}$ & $\begin{array}{l}0.013 \\
(1.81)^{*}\end{array}$ & $\begin{array}{l}-0.048 \\
(1.97)^{* *}\end{array}$ \\
\hline Heavy Mentally & $\begin{array}{l}0.104 \\
(2.54)^{* *}\end{array}$ & $\begin{array}{l}0.004 \\
(0.20)\end{array}$ & $\begin{array}{l}0.006 \\
(0.50)\end{array}$ & $\begin{array}{l}0.076 \\
(1.90)^{*}\end{array}$ \\
\hline No Promotion & $\begin{array}{l}0.084 \\
(3.80)^{* * *}\end{array}$ & $\begin{array}{l}0.040 \\
(3.35)^{* * *}\end{array}$ & $\begin{array}{l}0.017 \\
(2.76)^{* * *}\end{array}$ & $\begin{array}{l}-0.060 \\
(2.86)^{* * *}\end{array}$ \\
\hline Discrimination & $\begin{array}{l}0.099 \\
(4.43)^{* * *}\end{array}$ & $\begin{array}{l}0.063 \\
(4.82)^{* * *}\end{array}$ & $\begin{array}{l}0.009 \\
(1.41)\end{array}$ & $\begin{array}{l}0.037 \\
(1.69)^{*}\end{array}$ \\
\hline Shift Work & $\begin{array}{l}0.004 \\
(0.08)\end{array}$ & $\begin{array}{l}0.003 \\
(0.10)\end{array}$ & $\begin{array}{l}-0.001 \\
(0.07)\end{array}$ & $\begin{array}{l}-0.059 \\
(1.24)\end{array}$ \\
\hline Temporary & $\begin{array}{l}0.016 \\
(0.50)\end{array}$ & $\begin{array}{l}0.098 \\
(5.35)^{* * * *}\end{array}$ & $\begin{array}{l}0.052 \\
(4.79)^{* * * *}\end{array}$ & $\begin{array}{l}-0.030 \\
(0.97)\end{array}$ \\
\hline Part-Timer & $\begin{array}{l}-0.053 \\
(1.50)\end{array}$ & $\begin{array}{l}0.072 \\
(3.56)^{* * *}\end{array}$ & $\begin{array}{l}0.045 \\
(3.95)^{* * *}\end{array}$ & $\begin{array}{l}-0.050 \\
(1.50)\end{array}$ \\
\hline Fixed Pay & $\begin{array}{l}0.028 \\
(0.92)\end{array}$ & $\begin{array}{l}0.025 \\
(1.49)\end{array}$ & $\begin{array}{l}-0.008 \\
(0.89)\end{array}$ & $\begin{array}{l}-0.024 \\
(0.80)\end{array}$ \\
\hline Piece Rate & $\begin{array}{l}0.090 \\
(1.35)\end{array}$ & $\begin{array}{l}0.005 \\
(0.13)\end{array}$ & $\begin{array}{l}-0.009 \\
(0.59)\end{array}$ & $\begin{array}{l}-0.036 \\
(0.58)\end{array}$ \\
\hline Team Work & $\begin{array}{l}-0.027 \\
(1.20)\end{array}$ & $\begin{array}{l}0.006 \\
(0.46)\end{array}$ & $\begin{array}{l}-0.003 \\
(0.46)\end{array}$ & $\begin{array}{l}0.017 \\
(0.81)\end{array}$ \\
\hline Female & $\begin{array}{l}0.004 \\
(0.17)\end{array}$ & $\begin{array}{l}-0.021 \\
(1.68)^{*}\end{array}$ & $\begin{array}{l}-0.003 \\
(0.40)\end{array}$ & $\begin{array}{l}-0.045 \\
(2.07)^{* *}\end{array}$ \\
\hline Age & $\begin{array}{l}0.008 \\
(1.08)\end{array}$ & $\begin{array}{l}0.011 \\
(2.44)^{* *}\end{array}$ & $\begin{array}{l}0.002 \\
(0.71)\end{array}$ & $\begin{array}{l}-0.001 \\
(0.08)\end{array}$ \\
\hline Age Squared & $\begin{array}{l}-0.000 \\
(1.78)^{*}\end{array}$ & $\begin{array}{l}-0.000 \\
(3.24)^{* * *}\end{array}$ & $\begin{array}{l}-0.000 \\
(1.11)\end{array}$ & $\begin{array}{l}-0.000 \\
(0.98)\end{array}$ \\
\hline Married & $\begin{array}{l}-0.029 \\
(1.19)\end{array}$ & $\begin{array}{l}0.003 \\
(0.21)\end{array}$ & $\begin{array}{l}-0.003 \\
(0.41)\end{array}$ & $\begin{array}{l}0.017 \\
(0.72)\end{array}$ \\
\hline Spouse Working & $\begin{array}{l}0.023 \\
(0.98)\end{array}$ & $\begin{array}{l}-0.013 \\
(1.05)\end{array}$ & $\begin{array}{l}0.006 \\
(0.90)\end{array}$ & $\begin{array}{l}0.017 \\
(0.74)\end{array}$ \\
\hline Secondary Education & $\begin{array}{l}0.024 \\
(0.93)\end{array}$ & $\begin{array}{l}0.022 \\
(1.49)\end{array}$ & $\begin{array}{l}0.018 \\
(2.25)^{* *}\end{array}$ & $\begin{array}{l}-0.011 \\
(0.45)\end{array}$ \\
\hline Polytechnic Education & $\begin{array}{l}0.106 \\
(2.78)^{* * *}\end{array}$ & $\begin{array}{l}0.074 \\
(2.93)^{* * *}\end{array}$ & $\begin{array}{l}0.031 \\
(2.13)^{* *}\end{array}$ & $\begin{array}{l}0.015 \\
(0.42)\end{array}$ \\
\hline University Education & $\begin{array}{l}0.115 \\
(2.64) * * *\end{array}$ & $\begin{array}{l}0.049 \\
(1.76)^{*}\end{array}$ & $\begin{array}{l}0.019 \\
(1.16)\end{array}$ & $\begin{array}{l}0.004 \\
(0.09)\end{array}$ \\
\hline Union Member & $\begin{array}{l}-0.028 \\
(1.05)\end{array}$ & $\begin{array}{l}-0.004 \\
(0.29)\end{array}$ & $\begin{array}{l}-0.006 \\
(0.83)\end{array}$ & $\begin{array}{l}0.009 \\
(0.36)\end{array}$ \\
\hline Manager & $\begin{array}{l}0.008 \\
(0.35)\end{array}$ & $\begin{array}{l}0.001 \\
(0.08)\end{array}$ & $\begin{array}{l}0.001 \\
(0.18)\end{array}$ & $\begin{array}{l}0.022 \\
(1.00)\end{array}$ \\
\hline Tenure & $\begin{array}{l}0.009 \\
(2.12)^{* *}\end{array}$ & $\begin{array}{l}-0.004 \\
(1.17)\end{array}$ & $\begin{array}{l}-0.002 \\
(1.15)\end{array}$ & $\begin{array}{l}-0.006 \\
(1.47)\end{array}$ \\
\hline Tenure Squared & $\begin{array}{l}-0.000 \\
(3.12)^{* * *}\end{array}$ & $\begin{array}{l}-0.000 \\
(0.68)\end{array}$ & $\begin{array}{l}-0.000 \\
(0.24)\end{array}$ & $\begin{array}{l}0.000 \\
(1.47)\end{array}$ \\
\hline Different Occupations & $\begin{array}{l}-0.027 \\
(0.90)\end{array}$ & $\begin{array}{l}0.041 \\
(2.43)^{* *}\end{array}$ & $\begin{array}{l}0.009 \\
(1.05)\end{array}$ & $\begin{array}{l}-0.043 \\
(1.49)\end{array}$ \\
\hline
\end{tabular}




\begin{tabular}{l|llll}
\hline Number of Switches & 0.008 & 0.013 & 0.001 & 0.010 \\
& $(1.22)$ & $(3.33)^{* * *}$ & $(0.81)$ & $(1.52)$ \\
Public Sector & & & \\
& 0.020 & -0.011 & -0.000 & 0.097 \\
Foreign Firm & $(0.53)$ & $(0.60)$ & $(0.03)$ & $(2.66)^{* * *}$ \\
Plant Size 10-49 & 0.105 & -0.018 & -0.000 & $(0.04)$ \\
Plant Size 50-499 & $(2.61)^{* * *}$ & $(0.85)$ & $(0.02)$ & -0.022 \\
& -0.002 & -0.014 & -0.004 & $(0.89)$ \\
Plant Size $>499$ & $(0.07)$ & $(1.02)$ & $(0.62)$ & -0.032 \\
Growing Employment & -0.026 & -0.019 & -0.011 & $(1.13)$ \\
Unstable Firm & $(0.88)$ & $(1.19)$ & $(1.35)$ & 0.057 \\
& -0.015 & -0.011 & 0.001 & $(1.34)$ \\
Regional Unemployment & $(0.33)$ & $(0.47)$ & $(0.05)$ & 0.043 \\
& -0.000 & -0.004 & -0.010 & $(1.36)$ \\
Industry dummies & $(0.01)$ & $(0.21)$ & $(1.16)$ & 0.033 \\
Pseudo R & 0.065 & 0.014 & 0.001 & $(1.21)$ \\
Observations & $(2.29)^{* *}$ & $(0.88)$ & $(0.20)$ & -0.014 \\
\hline
\end{tabular}

NOTE: Robust z statistics are reported in parentheses; $*$ significant at $10 \%$; ** significant at $5 \%$; *** significant at $1 \%$. 


\begin{tabular}{|c|c|c|c|}
\hline & \multicolumn{3}{|c|}{ Dependent variable of multivariate model } \\
\hline Explanatory variable & $\begin{array}{l}\text { (1) Satisfied } \\
\text { (2) Switch } \\
\text { Intentions } \\
\text { (3) Actual Switch }\end{array}$ & $\begin{array}{l}\text { (1) Satisfied } \\
\text { (2) Searcher Last } \\
\text { Six Months } \\
\text { (3) Actual Switch }\end{array}$ & $\begin{array}{l}\text { (1) Satisfied } \\
\text { (2) Searcher Last } \\
\text { Four Weeks } \\
\text { (3) Actual Switch }\end{array}$ \\
\hline Harm & $\begin{array}{l}-0.304 \\
(4.72)^{* * *}\end{array}$ & $\begin{array}{l}-0.293 \\
(4.58) * * *\end{array}$ & $\begin{array}{l}-0.307 \\
(4.84)^{* * *}\end{array}$ \\
\hline Hazard & $\begin{array}{l}-0.075 \\
(1.22)\end{array}$ & $\begin{array}{l}-0.063 \\
(1.03)\end{array}$ & $\begin{array}{l}-0.053 \\
(0.87)\end{array}$ \\
\hline Uncertainty & $\begin{array}{l}-0.216 \\
(3.91)^{* * *}\end{array}$ & $\begin{array}{l}-0.193 \\
(3.54)^{* * *}\end{array}$ & $\begin{array}{l}-0.199 \\
(3.66)^{* * * *}\end{array}$ \\
\hline Heavy Mentally & $\begin{array}{l}-0.038 \\
(0.33)\end{array}$ & $\begin{array}{l}-0.024 \\
(0.22)\end{array}$ & $\begin{array}{l}-0.028 \\
(0.25)\end{array}$ \\
\hline No Promotion & $\begin{array}{l}-0.436 \\
(7.75)^{* * *}\end{array}$ & $\begin{array}{l}-0.444 \\
(7.96)^{* * * *}\end{array}$ & $\begin{array}{l}-0.442 \\
(7.96)^{* * * *}\end{array}$ \\
\hline Discrimination & $\begin{array}{l}-0.435 \\
(7.09)^{* * *}\end{array}$ & $\begin{array}{l}-0.432 \\
(7.10)^{* * *}\end{array}$ & $\begin{array}{l}-0.412 \\
(6.81)^{* * *}\end{array}$ \\
\hline (2) & & & \\
\hline Satisfied & $\begin{array}{l}-0.974 \\
(-9.08) * * *\end{array}$ & $\begin{array}{l}-0.912 \\
(-6.41)^{* * *}\end{array}$ & $\begin{array}{l}-1.038 \\
(-6.42)^{* * *}\end{array}$ \\
\hline $\begin{array}{l}\text { Wage } \\
\text { (3) }\end{array}$ & $\begin{array}{l}0.178 \\
(3.12)^{* *}\end{array}$ & $\begin{array}{l}-0.123 \\
(-1.87)^{*}\end{array}$ & $\begin{array}{l}-0.093 \\
(-1.18)\end{array}$ \\
\hline Switch Intentions & $\begin{array}{l}0.204 \\
(1.51)\end{array}$ & & \\
\hline $\begin{array}{l}\text { Searcher Last Six } \\
\text { Months }\end{array}$ & & $\begin{array}{l}0.021 \\
(0.16)\end{array}$ & \\
\hline $\begin{array}{l}\text { Searcher Last Four } \\
\text { Weeks }\end{array}$ & & & $\begin{array}{l}0.342 \\
(2.24) * *\end{array}$ \\
\hline Wage & $\begin{array}{l}0.341 \\
(5.54)^{* * *}\end{array}$ & $\begin{array}{l}0.339 \\
(5.69) * * *\end{array}$ & $\begin{array}{l}0.341 \\
(5.73)^{* * *}\end{array}$ \\
\hline
\end{tabular}

NOTE: Each column of the table reports the key variables of interest from one of the three different specifications of the multivariate probit model. The dependent variable in the second stage of the models is one of our three alternative quit intention measures, Switch Intentions, Searcher Last Six Months, or Searcher Last Four Weeks. Otherwise the structure of all three models is identical. The unreported control variables are explained in detail in the text; the results on them are available upon request. Robust $\mathrm{z}$ statistics are reported in parentheses; * significant at $10 \%$;** significant at $5 \%$; *** significant at $1 \%$. 


\section{APPENDIX}

\section{TABLE A1: DEFINITION OF VARIABLES AND DESCRIPTIVE STATISTICS}

Variable

Job switch intentions:

Switch Intentions

Would Switch to Same Field

Would Switch to Other Field

On-the-job search:

Searcher Last Six Months

Searcher Last Four Weeks

Actual job switch:

Actual Switch

Job satisfaction:

Satisfied

0.306

$(0.461)$

Wage:

Wage

Working conditions:

Harm

0.240
Definition/measurement

(standard

deviation)

$(0.427)$

Has looked for another job in the last six months $=1$, otherwise $=0$

Has looked for another job during the last four weeks $=1$, Otherwise $=0$

Has switched plant at least once during the period of 1998-2002 =1, Otherwise $=0$. Information is based on plant codes in FLEED.

Job satisfaction is measured by means of alternatives 1 (very satisfied), 2 (quite satisfied), 3 (rather dissatisfied), and 4 (very dissatisfied). The satisfied variable gets value one for the highest satisfaction category 1 , otherwise $=0$.

Logarithm of hourly earnings that is calculated based on the annual earnings (FIM) obtained from tax registers and by using regular weekly hours from LFS.

At least one adverse factor that affects work 'very much' (includes heat, cold, vibration, draught, noise, smoke, gas and fumes, humidity, dry indoor air, dust, dirtiness of work environment, poor or glaring lighting, irritating or corrosive substances, restless work environment, repetitive, monotonous movements, difficult or uncomfortable working positions, time pressure and tight time schedules, heavy lifting, lack of space, mildew in buildings) $=1$, otherwise $=0$ 
Hazard $\quad 0.338$

$(0.473)$

Uncertainty

0.577

(0.494)

Neglect

Heavy Mentally

No Promotion

Discrimation

Working time:

Shift Work

Temporary

0.180

$(0.385)$

Part-Timer

Payment system:

Fixed Pay

Piece Rate

Team Work

$(0.157)$

0.316

$(0.465)$

Human capital variables:

Female

Age

39.928

(10.487)

Age Squared

1687.546

(833.570)

Married

Spouse Working

0.558

$(0.497)$

Comprehensive Education

0.238

(0.426)

Secondary Education
At least one factor is experienced as 'a distinct hazard' (includes accident risk, becoming subject to physical violence, hazards caused by chemical substances, radiation hazard, major catastrophe hazard, hazard of infectious diseases, hazard of skin diseases, cancer risk, risk of strain injuries, risk of succumbing to mental disturbance, risk of grave work exhaustion, risk of causing serious injury to others, risk of causing serious damage to valuable equipment or product) $=1$, otherwise $=0$

Work carries at least one insecurity factor (includes transfer to other duties, threat of temporary dismissal, threat of permanent dismissal, threat of unemployment, threat of becoming incapable of work, unforeseen changes) $=1$, otherwise $=0$

At least one supportive factor 'never' experienced in work (includes advice or help, support and encouragement from superiors, support and encouragement from co-workers, feel of being a valued member of work community, opportunity to plan work, opportunity to apply own ideas in work, feel of own work as productive and useful) $=1$, otherwise $=0$

Current tasks mentally 'very demanding' $=1$, otherwise $=0$

Advancement opportunities in current workplace 'poor' $=1$, otherwise $=0$

Has fallen subject to at least one type of unequal treatment or discrimination in current workplace (includes time of hiring, remuneration, career advancement opportunities, access to training arranged by employer, receiving information, attitudes of co-workers or superiors) $=1$, otherwise $=0$

Uninterrupted 3-shift work $=1$, otherwise $=0$

Fixed-term employment relationship $=1$, otherwise $=0$

Part-time work $=1$, otherwise $=0$

Fixed monthly or hourly pay (including shift work supplement) $=1$, otherwise $=0$

Payment system is based on only piece-work or commission pay $=1$, otherwise $=0$

Works in teams 'almost all the time' or 'about three quarters of the time' $=1$, otherwise $=0$

$1=$ female, $0=$ male

Age of an employee

Age squared

Married $=1$, otherwise $=0$

Spouse is working $=1$, otherwise $=0$

Comprehensive education $=1$, otherwise $=0$ (reference)

Upper secondary or vocational education $=1$, otherwise $=0$ 
Polytechnic Education

0.115

(0.319)

University Education

0.087

(0.282)

0.791

Union Member

(0.407)

Manager

0.317

(0.466)

Work history:

Tenure

9.558

(9.317)

Tenure Squared

178.129

(275.245)

Different Occupations

Number of Switches

0.130

(0.336)

0.742

(1.645)

Information about employer:

Public Sector

0.343

(0.475)

Foreign Firm

0.071

(0.258)

Plant Size $<10$

0.276

(0.447)

Plant Size 10-49

0.363

(0.481)

Plant Size 50-499

0.280

(0.499)

Plant Size $>499$

(0.273)

Growing Employment

0.109

(0.311)

Unstable Firm

0.159

(0.365)

Regional variable:

Regional Unemployment

Indicators for industries and occupations:

Industries

Occupations
Polytechnic or lower university degree $=1$, otherwise $=0$

Higher university degree $=1$, otherwise $=0$

Member of trade union $=1$, otherwise $=0$

Tasks involve supervision of work of others or delegation of tasks $=1$, otherwise $=0$

Number of years in the current firm

Tenure squared

Has been in more than three distinctly different kinds of occupations during his/her life $=1$, otherwise $=0$ Number of job switches during the past five years

Employer is state or municipality $=1$, otherwise $=0$

Employer is private, mainly foreign-owned enterprise $=1$, otherwise $=0$

Size of plant under 10 employees $=1$, otherwise $=0$ (reference)

Size of plant 10-49 employees $=1$, otherwise $=0$

Size of plant 50-499 employees $=1$, otherwise $=0$

Size of plant over 499 employees $=1$, otherwise $=0$

The number of employees has increased in the plant during the past three years $=1$, otherwise $=0$

Financial situation is 'unstable' $=1$, otherwise $=0$

The regional unemployment rate based on 12 NUTS3-regions (Source: LFS by Statistics Finland).

14 dummies based on Standard Industry Classification 10 dummies based on the classification of occupations by SF 
${ }^{1}$ Laband and Lentz (1998), among others, estimate reduced-form models for intentions to quit. In a choice model we could think that a latent quit intention is the difference of random utilities in another job and the present job. However, since we have data only on the attributes of the current job, it is difficult to justify the model with a random utility framework.

${ }^{2}$ For this reason, we have examined the European Community Household Panel (ECHP) for Finland, which is available over the period 1998-2001. There have not been substantial changes in the average level of job satisfaction among wage and salary earners.

${ }^{3}$ The model is discussed, for example, in Maddala (1983) and Greene (2003). It is a special case of the model originally proposed by Heckman (1978).

${ }^{4}$ Using the exclusion restrictions also improves the validity of tests of exogeneity of the potentially endogenous explanatory dummy variables (essentially, tests of whether the correlations of the errors of the probit models are zero) when the distributional assumptions are misspecified (see Monfardini and Radice, 2006).

${ }^{5}$ Unemployment is almost three times higher in some regions of Eastern and Northern Finland compared to some regions in Southern Finland.

${ }^{6}$ As most quits involve moving to higher pay, it is likely that the measures of intentions that are available in the QWLS data do not fully pick up job search as the theory understands it.

${ }^{7}$ We note that there are also some other possible job switch intention measures, like retirement intentions and aspirations to become an entrepreneur. For example, Hyytinen and Ilmakunnas (2007) examine the determinants of entrepreneurial intentions using the QWLS data and find that job dissatisfaction increases entrepreneurial aspirations.

${ }^{8}$ To test whether this data problem matters, we included in the models an indicator for the subgroup who report a search over the past four weeks, but who do not report a search over the past six months. It is not statistically significant at the standard 5\% level in the models that are reported in the $1^{\text {st }}$ and the $4^{\text {th }}$ columns of Table 1 and the other results remain the same.

${ }^{9}$ We assume that a person is in the same job at the moment of the QWLS interview and at the end of December 1997. It is possible that a person has changed jobs between October and the end of December, but the number of this kind of persons is arguably not particularly large. We can link the QWLS data backward to FLEED and check the plant codes for the persons in the QWLS data in the year 1996. By doing this, we can calculate the number of persons that have changed their job during the whole of 1997 . It turns out that 821 persons $(27.6 \%$ of the total number of persons included in QWLS) changed their jobs during the year 1997 (i.e. between the end of December 1996 and the end of December 1997). If we assume that worker turnover has been constant within the year 1997 and all responses to the QWLS data are from September, we can obtain an estimate that some 200 persons (around 7\% of the total number of persons included in QWLS) changed their job between October and the end of December 1997. Since the interviews were spread out in the period between September and December, the likely number of job switchers is much smaller.

${ }^{10}$ It is important to keep in mind that the distinction between quits and layoffs is not clear from the theoretical perspective, because employers can always, at least in principle, decrease workers' wages in order to produce ('voluntary') quits.

11 We have tested whether job satisfaction directly explains employees' intentions to quit and actual job separations by using the models reported in Table 1. In general, job satisfaction is statistically significant with a negative coefficient as expected, but the results on job disamenities remain almost unchanged. The problem with the job satisfaction variable (Satisfied) is that it is arguably strongly endogenous in the equations, because job disamenities decrease job satisfaction, based on the evidence from the QWLS data (Böckerman and Ilmakunnas 2006).

${ }^{12}$ We have investigated the robustness of our baseline results by using different definitions for job disamenities. The definition of job disamenites (Harm, Hazard, Uncertainty, Neglect and Discrimination) can be made tighter by requiring that there must be at least three clearly adverse aspects at the workplace. For instance, in this case the average values for the Harm and Hazard variables are around 0.05 (i.e. 5 percent of the employees face 
harms or hazards), in comparison to the values 0.29 and 0.34 , respectively, in the baseline specification. Our results reported in Tables 1-2 are robust in this respect.

${ }^{13}$ In the same way, it has been a common finding in the literature on compensating wage differentials that job disamenities may obtain insignificant or even wrong-signed coefficients in the wage equations (e.g. Brown 1980). One reason for this is that groups of the labor force with very low unobserved productivity characteristics end up with poor jobs with adverse working conditions, but they have little bargaining power to negotiate higher wages.

${ }^{14}$ Broadly speaking, these findings are in line with the literature. For instance, Pissarides and Wadsworth (1994) discover that temporary or part-time employment encourages on-the-job search.

${ }^{15}$ We have estimated all models separately for the private sector and the public sector. There are evidently some differences in the results between the sectors. Nevertheless, job disamenities matter for employees' intentions to quit and on-the-job-search in both sectors. Furthermore, we have estimated reduced-form models where actual job mobility is explained with our measures of intentions to quit and the basic controls of Table 1. Those models reveal that all the alternative variables that capture intentions (Switch Intentions, Searcher Last Six Months and Searcher Last Four Weeks) are statistically significant explanatory variables for actual job switches.

${ }^{16}$ Wage is not included in the job satisfaction equation, because it is not a statistically significant explanatory variable for the level of job satisfaction.

${ }^{17}$ We have estimated the multivariate probit model also without a separate equation for employees' intentions to quit. This specification contains two equations. (One is for job satisfaction and the other one is for actual job switches, explained by quit intentions and job satisfaction.) In this case all the alternative variables that capture intentions (Switch Intentions, Searcher Last Six Months and Searcher Last Four Weeks) were statistically significant explanatory variables for actual job switches.

${ }^{18}$ When Searcher Last Four Weeks is one of the dependent variables in the three-equation probit model, the correlations of the errors of the probit equations are jointly significantly different from zero at the $1 \%$ level. 